\title{
The Effect of Heavy Metals on Miscarriage
}

Engin YILDIRIMa, (D) Mehmet Kürşat DERicib

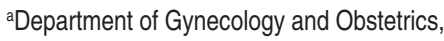
Hitit University Faculty of Medicine,

Çorum, TURKEY

'Department of Medical Pharmacology, Kırıkkale University Faculty of Medicine, Kırıkale, TURKEY

Received: 09.12.2018

Received in revised form: 28.01.2019

Accepted: 13.02.2019

Available online: 26.02 .2019

Correspondence:

Engin YILDIRIM

Hitit University Faculty of Medicine,

Department of Gynecology and Obstetrics, Corum, TURKEY

dreyildirim@gmail.com
Copyright (C) 2019 by Türkiye Klinikleri

\begin{abstract}
Objective: In a world where industrial pollution is increasing day by day, heavy metals are one of the important factors threatening human health. The rates of pregnancy loss and subfertility are continuously increasing. This study aims to explain the effects of lead $(\mathrm{Pb})$, cadmium $(\mathrm{Cd})$, and mercury $(\mathrm{Hg})$ levels on the etiology of abortions. Material and Methods: The study was designed as a case-control study with two groups: healthy volunteers $(n=20)$ and miscarriage $(n=29)$ group. The pregnant women with similar demographic characteristics were divided into two groups and peripheral venous blood samples of the study subjects were collected. Atomic absorption spectrophotometer was used to examine the blood samples and the levels of heavy metal. Results: While the $\mathrm{Pb}$ level was found to be higher in the miscarriage group $(\mathrm{p}=0.038)$, there was no statistical difference between $\mathrm{Cd}$ and $\mathrm{Hg}$ levels ( $\mathrm{p}>0.005$ ) in the two groups. On comparing the laboratory values of pregnant women in the control and miscarriage groups, blood progesterone values were observed to be lower in the miscarriage group $(\mathrm{p}<0.001)$. Conclusion: This study indicates that heavy metals, even below the toxic dose limits, can cause miscarriage. Higher blood Pb levels were found in the miscarriage group while $\mathrm{Hg}$ and $\mathrm{Cd}$ levels were not different between the two groups. This research points out that the high levels of lead may have an effect on pregnancy loss.
\end{abstract}

Keywords: Miscarriage; heavy metals; lead; cadmium, mercury

nvironmental pollution and industrialization expose humans to heavy metals in every period of their lives. Exposure to heavy metals affects the growth and development of a living being; therefore, it has become increasingly alarming in terms of public health. One of the environmental factors responsible for decreasing the chances of a healthy pregnancy and thus preventing a healthy birth is heavy metals. Both maternal and paternal heavy metal exposure may affect pregnancy. Occupational exposures to heavy metals have been associated with poor obstetric outcomes and adverse effects on female fertility.

Heavy metals have been proved to be environmental pollutants for all living creatures and humans. They may be present in the environment either naturally, or as industrial pollutants resulting from industrial accidents and various other reasons. The levels of heavy metals in blood have been found to be higher in countries with greater industrial development. ${ }^{1}$

Miscarriage is defined as a pregnancy that is spontaneously lost before 22 weeks of gestation and below $500 \mathrm{~g}$ fetal weight. Spontaneous abortion is largely becoming a public health concern for developing countries. ${ }^{2}$ Early pregnancy loss includes gestational sac that is empty before $126 / 7$ weeks of gestation or the presence of an embryo or fetus without cardiac 
activity. ${ }^{3}$ Approximately $10 \%$ of the clinically diagnosed pregnancies result in spontaneous abortion. ${ }^{4}$ Chromosomal anomalies are the most common etiologic factors causing spontaneous pregnancy loss. The most important factors that increase the risk of abortion include increased maternal age and previous abortions. ${ }^{5,6}$

Heavy metals like cadmium (Cd), lead $(\mathrm{Pb})$, and mercury $(\mathrm{Hg})$ have been found to affect reproductive success adversely along with causing environmental pollution. ${ }^{7}$ The mutagenic, teratogenic, and embryotoxic effects of Cd have been well documented in the literature. ${ }^{8}$ Heavy metal exposure during pregnancy has been shown to be associated with pre-eclampsia, preterm delivery, and low birth-weight deliveries while low selenium levels have also been suggested to contribute to preterm labor. ${ }^{9,10}$ It has been reported that exposure to environmental pollutants is associated with ovulation disorder, implantation failure and may also cause pregnancy loss and congenital anomalies. ${ }^{11} \mathrm{Cd}$ is the heavy metal that is used in battery mechanization, pigment technology, and plastic industry. Smokers, as well as those exposed to passive cigarette smoke, may also be exposed to Cd toxicity. The most frequent exposure to $\mathrm{Cd}$, resulting from environmental factors is smoking and some vegetables. Cd levels have been found to be high in the blood and placentas of pre-eclamptic women. ${ }^{12}$ Molecular level examinations have revealed that some organisms use specific mechanisms, which may help avoid the toxicity of the Cd in order to overcome its harmful effects. Metallothioneins (MTs) play an important role in these mechanisms. MTs are a family of proteins, rich in cysteine, and range in size from small to medium. In all eukaryotes and some prokaryotes, they have the ability to coordinate metal ions through metal-thiolate bonds. ${ }^{13} \mathrm{Cd}$ toxicity inhibits the transmission of zinc ( $\mathrm{Zn}$ ) from the mother to the fetus, induces MT gene expression in specific tissues and causes the Zn-MT complex to change to Cd-MT complex. ${ }^{14}$ These changes at the molecular level impair the maternofetal relationship and adversely affect fetal development.

Lead toxicity is one of the most well-known heavy metal-borne clinical conditions because it is one of the most easily exposed heavy metals caused by environmental factors. $\mathrm{Pb}$ toxicity affects the hematopoietic system, nervous system, reproductive system, urinary system, and blood pressure. ${ }^{15}$ It has been shown that exposure to $\mathrm{Pb}$ during pregnancy may cause accumulation in the fetal tissues and cause irreversible tissue and organ damage. ${ }^{16} \mathrm{~Pb}$ has been shown to cause premature delivery and premature rupture of the membrane, even at non-toxic doses. ${ }^{17}$ An increase in $\mathrm{Pb}$ levels in maternal blood has been found to be associated with a decrease in the birth weight of newborns, head circles, and crown-heel length. ${ }^{18}$

Another heavy metal, known to be neurotoxic and may also be embryotoxic and fetotoxic during pregnancy, is Hg. ${ }^{19}$ The consumption of contaminated seafood, water, and air pollution, use of some creams and teething powder may cause $\mathrm{Hg}$ exposure. ${ }^{20}$ Dental amalgams contain approximately $50 \%$ of elemental $\mathrm{Hg}$. In the $\mathrm{UK}$, it is recommended to avoid or remove dental amalgam during pregnancy. ${ }^{21}$ It has been observed that $\mathrm{Hg}$ causes organ and tissue damage by disrupting DNA and RNA structure in intra-uterine life. ${ }^{22}$ Children have been found to be born with anomalies such as microcephaly, cerebral palsy, severe mental retardation, seizure disorders, deafness, and visual impairment even in cases where mothers were not affected after $\mathrm{Hg}$ exposure. ${ }^{23}$

Approximately $80 \%$ of all cases of pregnancy loss occur in the first trimester. ${ }^{9}$ Spontaneous miscarriages may also be a marker of embryotoxicity. This study aims to elucidate the role of heavy metals in pregnancy loss by comparing serum $\mathrm{Cd}, \mathrm{Pb}$, and $\mathrm{Hg}$ levels in women who have had spontaneous miscarriages even though fetal heart rate was detected in the previous pregnancies, compared to women with healthy pregnancies.

\section{MATERIAL AND METHODS}

\section{POPULATION AND DESIGN OF THE STUDY}

The study had a case-control design and was conducted between December 2017 and August 2018 at the Department of Obstetrics and Gynecology, Faculty of Medicine, Hitit University, Corum, Turkey. 
There were two groups; the first group was defined as the control group and consisted of 20 healthy singleton pregnancies in women aged 1840 years. The second group (miscarriage group) consisted of 29 singleton pregnancies in women between the ages of 18-40 years, in whom the pregnancy was found to have stopped at the first trimester of fetal heart rate. Prior to the study, the Ethics Committee approval was obtained from the Faculty of Medicine, Hitit University, in accordance with the Helsinki Declaration. The approval date of the ethics committee is 19 December 2017 and the acceptance number is 2017-201. Informed consent was obtained from all participants.

The inclusion and exclusion criteria for the control and the miscarriage groups are defined in Table 1 and Table 2, respectively.

In total, 188 pregnant women were included in the study from the beginning till the end of the investigation. The reasons for the removal of pregnant women from the study were smoking (61), a history of dental amalgam (23), receiving additional medication (16), having worked in industrial jobs with high levels of heavy metal pollution (13), refusing to participate in the study (11), uncoopera- tive due to language problem (9), and those who voluntary withdrawn from the study (6).

The socio-demographic characteristics, smoking history and medical history of the patients were recorded using the face-to-face questionnaire method. All participants were living in the center of Corum (Turkey). Ultrasonographic evaluations of the pregnant women were performed using the GE Logiq P5 (2015, GE Healthcare, Milwaukee WI) device with a transvaginal probe in the obstetrics clinic. Although the embryo was detected in the ultrasonographic examination, the pregnant women whose fetal heart rate could not be detected were accepted as miscarriage and referred to the Radiology Clinic of Hitit University for being included as ultrasonography controls $(n=3)$. The pregnant women with an audible fetal heart rate were included in the study. The data from thyroid function tests, toxoplasma, rubella, cytomegalovirus (CMV), and herpes simplex virus and other laboratory findings were recorded in the hospital automation system.

\section{MEASUREMENT OF THE SERUM HEAVY METAL CONCENTRATIONS}

Peripheral venous blood was obtained after the ultrasonographic evaluation of pregnant women in

\begin{tabular}{|ll|}
\hline \multicolumn{1}{|c|}{ TABLE 1: } & Inclusion criteria for the control and miscarriage groups. \\
\hline Control group $(\mathrm{n}=\mathbf{2 0})$ & Miscarriage group $(\mathrm{n}=\mathbf{2 9})$ \\
\hline Age between $18-40$ & Age between $18-40$ \\
\hline Singular pregnancy & Singular pregnancy \\
Last menstruation date should be on record & Last menstruation date should be on record \\
Having regular ultrasonographic record during the pregnancy period & Having regular ultrasonographic record during the pregnancy period \\
Having normal ultrasonographic findings & It should have been confirmed independently by two physicians that there is no fetal heartbeat \\
\hline
\end{tabular}

TABLE 2: Exclusion criteria for the control and miscarriage groups.

\begin{tabular}{|c|c|}
\hline \multicolumn{2}{|c|}{$\begin{array}{c}\text { The exclusion criteria } \\
\text { (Both groups) }\end{array}$} \\
\hline $\begin{array}{l}\text { - Presence of dental amalgam } \\
\text { - Working in jobs with high industrial pollution } \\
\text { - Receiving lithium or metal-containing medication } \\
\text { - Taking additional medication except for folic acid } \\
\text { - Having high-risk in the dual or triple screening test } \\
\text { - Being diagnosed with cervical insufficiency } \\
\text { - Having a homozygous thrombophilia gene mutation } \\
\text { - Obtaining medication for induced abortion }\end{array}$ & $\begin{array}{l}\text { - Being above } 40 \text { years of old } \\
\text { - Chronic drug use } \\
\text { - Impaired kidney and liver function tests } \\
\text { - Smoking } \\
\text { - Having one of the Müllerian anomalies } \\
\text { - Having two heterozygous thrombophilia gene mutations } \\
\text { - Presence of myoma uteri, which disturbs the morphology of the uterus or compresses the endometrial cavity }\end{array}$ \\
\hline
\end{tabular}


the control group while it was taken from the patients in the miscarriage group just before the evacuation of uterine cavities. Of the blood, $10 \mathrm{~mL}$ was aspirated into spray-coated tubes with sodium heparin and stored at $-80^{\circ} \mathrm{C}$ in a deep freezer.

\section{REAGENTS}

Analytical grade chemicals, prescribed for trace element analysis, were used. For the sample preparation, $65 \%(\mathrm{v} / \mathrm{v})$ nitric acid $\left(\mathrm{HNO}_{3}\right)$ (SigmaAldrich Corp, St Louis, MO, USA), 70\% (m/v) perchloric acid $\left(\mathrm{HClO}_{4}\right)$ (Merck, Darmstadt, Germany), and Triton X-100 (Sigma-Aldrich Corp, St Louis, MO, USA) were used. The working standard solutions for $\mathrm{Cd}, \mathrm{Hg}$, and $\mathrm{Pb}\left(1000 \mathrm{mg} \mathrm{mL}^{-1}\right)$ were obtained from Chem-Lab, Zedelgem, Belgium.

\section{SAMPLE PREPARATION AND DIGESTION}

In order to measure $\mathrm{Cd}$ level, $1 \mathrm{~mL}$ of whole blood sample was accurately measured using a graduated cylinder and automatic pipette (pipette head was washed with solvent) and then added into a propylene tube. Into the same tube, $9 \mathrm{~mL}$ of $4: 1$ $\mathrm{HNO}_{3}: \mathrm{HClO}_{4}$ mixture was added. A clean glass bar was used to shake the mixture. After waiting for approximately $10 \mathrm{~min}$ for the removal of gas, the mixture was put into a water bath. The mixture was digested in a water bath at $80^{\circ} \mathrm{C}$ for $2 \mathrm{~h}$ and was removed from the water bath when the samples became colorless. After cooling, the colorless solutions were transferred into $10-\mathrm{mL}$ volumetric flasks and made up to the volume with $5 \% \mathrm{HNO}_{3}$ in water. In order to measure $\mathrm{Hg}$ and $\mathrm{Pb}$ levels, $1 \mathrm{~mL}$ of each sample was mixed with $6 \mathrm{~mL}$ of $\mathrm{HNO}_{3}$ solution and $3 \mathrm{~mL}$ of Triton X-100 solution. After this, the same digestion method, described for $\mathrm{Cd}$, was followed. ${ }^{24-26}$

\section{APPARATUS}

The Optimize Furnace Parameters Wizard with SOLAAR (Thermo Scientific, Cambridge, England) software was used to determine the most suitable temperature and flow rate for analyzing the digested samples for all the elements. The automatic sampler was used to optimize the position of the injection capillaries and to observe the specimen being left in the cuvette. Of each elemental solution, $10 \mu \mathrm{g} / \mathrm{L}$ was used as the main standard. The au- tomatic sampler was programmed to automatically set the calibration standards in the appropriate range. All samples, blanks, and standards were injected at a constant fixed volume of $10 \mu \mathrm{L}$, alongside an additional aliquot of $10 \mu \mathrm{L}$ of the matrix modifier into an Electrographite cuvette. Cd was analyzed at $228.8 \mathrm{~nm}, \mathrm{Hg}$ was analyzed at $253.7 \mathrm{~nm}$ and $\mathrm{Pb}$ was analyzed at $217.0 \mathrm{~nm}$; Zeeman background correction was used throughout the process. Peak areas were measured for calibration and subsequent determination of the sample concentrations. The value of $R^{2}$ of the calibration curve was higher than 0.995 . Finally, after striking with dilution factor, the result was received as $\mathrm{ppb}\left(\mu \mathrm{g} \mathrm{L} \mathrm{L}^{-1}\right) .^{24}$

\section{STATISTICAL ANALYSIS}

All statistical analyses were performed with SPSS (Version 22.0, SPSS Inc., Chicago, IL, USA) package program. The distribution of normality was analyzed by the Shapiro-Wilk test. Descriptive statistics were presented as mean \pm standard deviation or median (min-max) according to data distribution for continuous variables. Parametric data of the groups were compared with Student's $t$-test while the nonparametric data were compared with the Mann-Whitney $\mathrm{U}$ test. The relationship between the diagnosis and categorical variables was investigated by either chisquare test or Fisher's exact test. A p-value $<0.05$ was considered to be statistically significant.

\section{RESULTS}

Among the control group and miscarriage group, there was no statistically significant difference between age, body mass index (BMI), and the gestational age calculated by the last menstrual date ( $>0.005)$. CRL (Crown-Rump Length) values of the pregnant women in the miscarriage group were found to be smaller than those of the gestational weeks calculated by ultrasonographic measurements done at the time they were included in the study. This difference was statistically significant ( $\mathrm{p}=0.001$, Table 3$)$.

Categorical variables of the study groups, such as blood group, were evaluated by the chi-square test or Fisher's exact test. There was no difference between the control and miscarriage groups in 
TABLE 3: Demographic characteristics of groups.

\begin{tabular}{|lccc|}
\hline & $\begin{array}{c}\text { Control } \\
(\mathbf{n}=20)\end{array}$ & $\begin{array}{c}\text { Miscarriage } \\
(\mathbf{n}=29)\end{array}$ & p-value \\
Age (years) & $25.40 \pm 3.60$ & $24.62 \pm 4.17$ & $0.501^{\text {a }}$ \\
& $(19.00-31.00)$ & $(18.00-33.00)$ & \\
USG (weeks) & $12.55 \pm 2.89$ & $9.86 \pm 2.62$ & $0.001^{\text {a }}$ \\
& $(7.00-18.00)$ & $(6.00-16.00)$ & \\
SAT (weeks) & $14.15 \pm 2.56$ & $12.37 \pm 1.91$ & $0.008^{\mathrm{a}}$ \\
& $(9.00-18.00)$ & $(9.00-17.00)$ & \\
BMI $\left(\mathrm{kg} / \mathrm{m}^{2}\right)$ & $22.14 \pm 2.00$ & $22.10 \pm 2.10$ & $0.943^{\mathrm{b}}$ \\
\hline
\end{tabular}

aMann-Whitney U test, ' $S$ Student's t-test

USG: Ultrasonography; LMD: Last menstrual date; BMI: Body mass index, CD: Cesarean delivery.

terms of frequency of blood groups and Rh antigen ( $p>0.005)$. The indirect Coombs test was negative in $\mathrm{Rh}(-)$ pregnant women in control and miscarriage groups. There was no significant relationship between the volunteers in both groups with respect to the diagnosis, gravida, parity, living children, and abortions ( $\mathrm{p}>0.005)$. Of the pregnant women, $65 \%$ in the control group and $51.7 \%$ in the miscarriage group had normal birth; the difference was statistically significant $(\mathrm{p}=0.015)$.

The infectious parameters for both groups were determined. Toxoplasma IgM, HbS Ag, CMV IgM, Rubella IgM, anti-HCV, and anti-HIV tests were found to be negative. No statistically significant difference was found between the control and miscarriage groups in the anti-Toxoplasma IgG, HBs IgG, CMV IgG, and Rubella IgG tests ( $p>0.005$ ).

There was no statistically significant difference between $\mathrm{Cd}$ and $\mathrm{Hg}$ levels ( $\mathrm{p}>0.005$ ) in the blood of control and miscarriage groups. However, blood $\mathrm{Pb}$ levels in the miscarriage group were found to be significantly higher ( $\mathrm{p}=0.038$, Table 4$)$. When the laboratory values in the control and miscarriage groups were compared, blood progesterone values were observed to be lower in the miscarriage group $(p<0.001)$. Additionally, blood calcium levels of the women in the miscarriage group were lower than those in the control group ( $\mathrm{p}=0.010)$ (Table 5).

\section{DISCUSSION}

The study aimed to understand the role of $\mathrm{Cd}, \mathrm{Pb}$, and $\mathrm{Hg}$ in the etiology of pregnancy loss during early gestational weeks. According to the spectrophotometric analysis, $\mathrm{Pb}$ levels were found to be higher in the miscarriage group as compared to that in the control group. On the basis of the analyzed results, we conclude that the possibility of chronic exposure to $\mathrm{Pb}$ from outside sources is low and $\mathrm{Pb}$ is also one of the factors involved in the etiology of miscarriage.

In this study, the levels of the heavy metals were found to below the limits suggested by the World Health Organization (WHO) and other organizations as threatening. ${ }^{27-29}$ The authors concluded that the elevation in blood $\mathrm{Pb}$ level may be related to miscarriage. There have been reports investigating the $\mathrm{Pb}$ level in the blood of pregnant women. In a study, in which $\mathrm{Cd}$ and $\mathrm{Pb}$ levels were examined in blood and placental tissues, $\mathrm{Pb}$ levels were found to be higher in the blood and placental tissues of the pregnant women..$^{30}$ Similarly, in the

\begin{tabular}{|c|c|c|c|}
\hline & $\begin{array}{l}\text { Control } \\
(n=20)\end{array}$ & $\begin{array}{l}\text { Miscarriage } \\
\quad(n=29)\end{array}$ & p-value \\
\hline Lead $(\mu / L)$ & $44.45 \pm 12.49$ & $54.11 \pm 17.27$ & $0.038^{*}$ \\
\hline Cadmium $(\mu / L)$ & $0.40 \pm 0.05$ & $0.39 \pm 0.06$ & $0.704^{*}$ \\
\hline Mercury $(\mu / L)$ & $0.46 \pm 0.27$ & $0.47 \pm 0.29$ & $0.907^{\star}$ \\
\hline
\end{tabular}

* Student's t-test

\begin{tabular}{|c|c|c|c|}
\hline \multicolumn{4}{|c|}{ TABLE 5: Laboratory findings. } \\
\hline & $\begin{array}{l}\text { Control } \\
(n=20)\end{array}$ & $\begin{array}{c}\text { Miscarriage } \\
\qquad(n=29)\end{array}$ & p-value \\
\hline $\mathrm{Hb}(\mathrm{g} / \mathrm{dL})$ & $11.54 \pm 1.24$ & $11.44 \pm 1.08$ & 0.583 \\
\hline Glucose (mg/dL) & $89.53 \pm 8.62$ & $90.20 \pm 8.59$ & 0.790 \\
\hline Creatine (mg/dL) & $0.68 \pm 0.12$ & $0.68 \pm 0.13$ & 0.834 \\
\hline TSH (ulU/mL) & $1.71 \pm 0.34$ & $1.95 \pm 0.59$ & 0.053 \\
\hline Progesterone (ng/mL) & $40.45 \pm 5.22$ & $10.30 \pm 2.11$ & $<0.001^{*}$ \\
\hline Hba1c & $5.22 \pm 0.54$ & $4.93 \pm 0.47$ & 0.069 \\
\hline AST (U/L) & $24.89 \pm 4.23$ & $24.35 \pm 4.031$ & 0.986 \\
\hline $\operatorname{ALT}(\mathrm{U} / \mathrm{L})$ & $21.29 \pm 2.96$ & $21.37 \pm 3.76$ & 0.933 \\
\hline $\mathrm{Na}(\mathrm{mmol} / \mathrm{L})$ & $139.39 \pm 3.05$ & $138.41 \pm 3.56$ & 0.421 \\
\hline $\mathrm{K}(\mathrm{mmol} / \mathrm{L})$ & $3.96 \pm 0.24$ & $3.89 \pm 0.32$ & 0.768 \\
\hline $\mathrm{Cl}(\mathrm{mmol} / \mathrm{L})$ & $99.36 \pm 3.83$ & $98.36 \pm 3.26$ & 0.348 \\
\hline $\mathrm{Ca}(\mathrm{mmol} / \mathrm{L})$ & $8.75 \pm 0.17$ & $8.93 \pm 0.29$ & $0.010^{*}$ \\
\hline
\end{tabular}

* Student's t-test

Hb: Hemoglobin; TSH: Thyroid-stimulating hormone; Hba1c: Hemoglobin A1c; AST: Aspartate aminotransferase; ALT: Alanine aminotransferase; Na: Sodium; K: Potassium; Cl: Chloride; Ca: Calcium. 
present study, the blood $\mathrm{Pb}$ levels were also higher. In another study, placental tissues were examined and heavy metal levels of the placental tissues were compared. The transplacental transition of heavy metals is variable in pregnancy. ${ }^{31}$ Therefore, in the present study, heavy metal levels in the placenta and aborted material were not compared.

When the miscarriage group was compared with the control group, no statistically significant difference between $\mathrm{Cd}$ levels in the mother's blood was observed. However, an earlier report based on the clinical data of pregnant women with high Cd levels showed more recurrent miscarriages. ${ }^{32}$ In a study in which blood and placental tissues were evaluated together, Cd levels were higher in the miscarriage group. ${ }^{30}$ High blood levels of $\mathrm{Pb}, \mathrm{Cd}$, and $\mathrm{Hg}$ have been shown to reduce pregnancy rates in a study examining the effect of heavy metal levels on fertility outcomes. ${ }^{33}$

When serum $\mathrm{Hg}$ levels of the miscarriage group and the control group were compared, no significant difference was found between them. The literature reports studies stating that high maternal $\mathrm{Hg}$ levels result in poor obstetric outcomes. In a study examining $\mathrm{Hg}$ levels in maternal blood, it was found that the developmental scores of the children born to mothers with high blood $\mathrm{Hg}$ levels were lower during 35-48 months. ${ }^{34}$ The mothers with high $\mathrm{Hg}$ levels gave birth to shorter babies (in terms of length) and with lower birth weights. ${ }^{35}$

We found blood progesterone levels to be higher in the healthy pregnancies. Although, there has been no prescribed limit of progesterone level to identify abnormal pregnancies, the best limit in early gestational weeks has been shown to be 10 $\mathrm{ng} / \mathrm{mL} .{ }^{36}$ A study examining early risk factors for miscarriage showed a higher risk of lower serum progesterone levels $(<12 \mathrm{ng} / \mathrm{mL}) \cdot{ }^{37}$ In the present study, serial progesterone level measurements were not performed and, instead, single value measurements were considered.

One of the limitations of the present study was that the variables related to the living areas of the participants were not considered. For example, although there were comprehensive inclusion and exclusion criteria for the participants, it was not recorded for the patients whether they have lived in a heavy metal contaminated area. Further, it was controlled that the patients were not smokers but we did not inquire if they had been exposed to passive cigarette smoke at home or in their social lives. The low number of participants (total number of pregnant females was 49) could be considered as another limitation of the study. Further, it was not possible to search for organ anomalies, genetic screening and culture of embryos in post-curettage pathologies of the miscarriage group. Therefore, inadequate pathological evaluation of the aborted material is also a limitation of the study.

\section{CONCLUSION}

Exposure to heavy metals may adversely affect the health of pregnant women. Even if the levels of heavy metals in the blood are below the toxic dose limits, it can cause miscarriage. This study found higher blood $\mathrm{Pb}$ levels in the miscarriage group. Further research in a larger population sample is required to confirm these results and to elucidate the mechanism of the interaction between heavy metals and miscarriage.

\section{Source of Finance}

During this study, no financial or spiritual support was received neither from any pharmaceutical company that has a direct connection with the research subject, nor from a company that provides or produces medical instruments and materials which may negatively affect the evaluation process of this study.

\section{Conflict of Interest}

No conflicts of interest between the authors and / or family members of the scientific and medical committee members or members of the potential conflicts of interest, counseling, expertise, working conditions, share holding and similar situations in any firm.

\section{Authorship Contributions}

Idea/Concept: Engin Yıldırım; Design: Engin Yıldırım; Control/Supervision: Engin Yıldırım; Data Collection and/or Processing: Engin Yıldırım; Analysis and/or Interpretation: Mehmet Kürşat Derici; Literature Review: Engin Yıldırım; Writing the Article: Engin Yıldırım; Critical Review: Mehmet Kürşat Derici; References and Fundings: Engin Yıldırım, Mehmet Kürşat Derici; Materials: Engin Yıldırım, Mehmet Kürşat Derici. 


\section{REFERENCES}

1. Man M, Naidu R, Wong MH. Persistent toxic substances released from uncontrolled ewaste recycling and actions for the future. Sci Total Environ. 2013;463-464:1133-7. [Crossref] [PubMed]

2. WHO: recommended definitions, terminology and format for statistical tables related to the perinatal period and use of a new certificate for cause of perinatal deaths. Modifications recommended by FIGO as amended October 14, 1976. Acta Obstet Gynecol Scand. 1977;56(3):247-53. [PubMed]

3. National Institute for Health and Clinical Excellence. Ectopic pregnancy and miscarriage: diagnosis and initial management in early pregnancy of ectopic pregnancy and miscarriage. NICE Clinical Guideline 154. Manchester (UK): NICE; 2012. (date of access: 25.01.2019). [Link]

4. Jelliffe-Pawlowski LL, Miles SQ, Courtney JG, Materna B, Charlton V. Effect of magnitude and timing of maternal pregnancy blood lead $(\mathrm{Pb})$ levels on birth outcomes. J Perinatol. 2006:26(3):154-62. [Crossref] [PubMed]

5. Alijotas-Reig J, Garrido-Gimenez C. Current concepts and new trends in the diagnosis and management of recurrent miscarriage. Obstet Gynecol Surv. 2013;68(6):445-66. [Crossref] [PubMed]

6. Practice Committee of the American Society for Reproductive Medicine. Evaluation and treatment of recurrent pregnancy loss: a committee opinion. Fertil Steril. 2012;98(5):110311. [Crossref] [PubMed]

7. Flora SJS, Pachauri V, Saxena G. Arsenic, cadmium and lead. In: Gupta RC, ed. Reproductive and Developmental Toxicology. $1^{\text {st }}$ ed. London: Elsevier; 2011. p.415-39. [Crossref]

8. Carmichael NG, Backhouse BL, Winder C, Lewis PD. Teratogenicity, toxicity and perinatal effects of cadmium. Hum Toxicol. 1982;1(2):159-86. [Crossref] [PubMed]

9. Wang X, Chen C, Wang L, Chen D, Guang W, French J. Conception, early pregnancy loss, and time to clinical pregnancy: a populationbased prospective study. Fertil Steril. 2003;79(3):577-84. [Crossref]

10. Yıldırım E, Derici MK, Demir E, Apaydın H, Koçak Ö, Kan Ö, et al. Is the concentration of cadmium, lead, mercury, and selenium related to preterm birth? Biol Trace Elem Res. 2019;17. [Crossref]

11. Foster WG, Neal MS, Han MS, Dominguez MM. Environmental contaminants and human infertility: hypothesis or cause for concern? J
Toxicol Environ Health B Crit Rev. 2008;11(34):162-76. [Crossref] [PubMed]

12. Wang $F$, Fan F, Wang L, Ye W, Zhang $Q$, Xie $\mathrm{S}$. Maternal cadmium levels during pregnancy and the relationship with preeclampsia and fetal biometric parameters. Biol Trace Elem Res. 2018;186(2):322-9. [Crossref] [PubMed]

13. Blindauer CA, Leszczyszyn Ol. Metallothioneins: unparalleled diversity in structures and functions for metal ion homeostasis and more. Nat Prod Rep. 2010;27(5):720-41. [Crossref] [PubMed]

14. Artells E, Palacios Ò, Capdevila M, Atrian S. Mammalian MT1 and MT2 metallothioneins differ in their metal binding abilities. Metallomics. 2013;5(10):1397-410. [Crossref] [PubMed]

15. Gidlow DA. Lead toxicity. Occup Med (Lond). 2004;54(2):76-81. [Crossref]

16. Semczuk M, Semczuk-Sikora A. New data on toxic metal intoxication $(\mathrm{Cd}, \mathrm{Pb}$, and $\mathrm{Hg}$ in particular) and $\mathrm{Mg}$ status during pregnancy. Med Sci Monit. 2001;7(2):332-40. [PubMed]

17. Fahim MS, Fahim Z, Hall DG. Effects of subtoxic lead levels on pregnant women in the state of Missouri. Res Commun Chern Pathol Pharmacol. 1976;13(2):309-31. [PubMed]

18. Taylor CM, Tilling K, Golding J, Emond AM. Low level lead exposure and pregnancy outcomes in an observational birth cohort study: dose-response relationships. BMC Res Notes. 2016;9:291. [Crossref] [PubMed] [PMC]

19. Nordberg GF, Fowler BA, Nordberg M, Friberg LT. Handbook on the Toxicology of Metals. $3^{\text {rd }}$ ed. London: Elsevier; 2007. p.975.

20. United States Environmental Protection Agency (US EPA). Economic Analysis of Including Mercury Containing Devices in the Universal Waste System, Notice of Proposed Rulemaking. Washington: Office of Solid Waste and Emergency Response; 2002.

21. Wild JR, Metters J. Dental amalgam. London: Department of Health Child Dental Officer; 1998.

22. Klaassen C. Casarett and Doull's Toxicology The Basic Science of Poisons. In: Tokar EJ, Boyd WA, Freedman JH, Waalkes MP, eds. Toxic effects of Metals. $8^{\text {th }}$ ed. New York: McGraw Hill Education; 2013. p.997-8.

23. Yorifuji T, Tsuda T, Takao S, Harada M. Longterm exposure to methylmercury and neurologic signs in Minamata and neighboring communities. Epidemiology. 2008;19(1)3-9. [Crossref] [PubMed]
24. Karaer A, Tuncay G, Tanrikut E, Ozgul 0 . Blood cadmium concentrations in women with ectopic pregnancy. Biol Trace Element Res. 2018;184(1):42-6. [Crossref] [PubMed]

25. Kebbekulus BB. Preparation of samples for metals analysis. Vol 162. In: Mitra S, ed. Sample Preparation Techniques in Analytical Chemistry. Canada: Wiley Interscience; 2003. p.227-70. [Crossref]

26. Takeda SHK, Kuno R, Barbosa F Jr, Gouveia $N$. Trace element levels in blood and associated factors in adults living in the metropolitan area of São Paulo, Brazil. J Trace Elem Med Biol. 2017;44:307-14. [Crossref] [PubMed]

27. World Health Organization (WHO). Health Risks of Heavy Metals from Long-Range Transboundary Air-Pollution. Copenhagen: WHO Regional Office for Europe; 2007. p.129. (date of access: 25.01.2019) [Link]

28. Centers for Disease Control and Prevention. Ettinger AS, Wengrovitz AG, Portier C, Brown MJ. Guidelines for the identification and management of lead exposure in pregnant and lactating women. Atlanta, GA: US Department of Health and Human Services; 2010. p.267. (date of access: 25.01.2019). [Link]

29. Committee Opinion. Lead screening during pregnancy and lactation. Committee Opinion Number: 533. American College of Obstetricians and Gynecologists; 2012. p.5. (date of access: 25.01.2019). [Link]

30. Omeljaniuk WJ, Socha K, Soroczynska J, Charkiewicz AE, Laudanski T, Kulikowski $\mathrm{M}$, et al. Cadmium and lead in women who miscarried. Clin Lab. 2018;64(1):59-67. [Crossref]

31. Hu H, Téllez-Rojo MM, Bellinger D, Smith D, Ettinger AS, Lamadrid-Figueroa $\mathrm{H}$, et al. Fetal lead exposure at each stage of pregnancy as a predictor of infant mental development. Environ Health Perspect. 2006;114(11):1730-5. [Crossref] [PubMed] [PMC]

32. Durska G. [Levels of lead and cadmium in pregnant women and newborns and evaluation of their impact on child development]. Ann Acad Med Stetin. 2001:47:49-60. [PubMed]

33. Bloom MS, Fujimoto VY, Steuerwald AJ, Cheng G, Browne RW, Parsons PJ. Background exposure to toxic metals in women adversely influences pregnancy during in vitro fertilization (IVF). Reprod Toxicol. 2012;34(3): 471-81. [Crossref] [PubMed] 
34. Lederman SA, Jones RL, Caldwell KL, Rauh $V$, Sheets SE, Tang D, et al. Relation between cord blood mercury levels and early child development in a World Trade Center cohort. Environ Health Persp. 2008;116(8):1085-91. [Crossref] [PubMed] [PMC]

35. Unuvar E, Ahmadov H, Kiziler AR, Aydemir B, Toprak S, Ulker V, et al. Mercury levels in cord blood and meconium of healthy newborns and venous blood of their mothers: clinical, prospective cohort study. Sci Total Environ. 2007;374(1):60-70. [Crossref] [PubMed]

36. Cowan BD, Vandermolen DT, Long CA, Whitworth NS. Receiver-operator characteristic, efficiency analysis, and predictive value of serum progesterone concentration as a test for abnormal gestations. Am J Obstet Gynecol. 1992;166(6 Pt 1):1729-34. [Crossref]

37. Arck PC, Rücke M, Rose M, Szekeres-Bartho J, Douglas AJ, Pritsch M, et al. Early risk factors for miscarriage: a prospective cohort study in pregnant women. Reprod Biomed Online. 2008;17(1):101-13. [Crossref] 